\title{
THE HISTORY OF THE LAW OF ADOPTION IN SOUTH AFRICA
}

\author{
Glynis van der Walt \\ BJuris LLB LLM
}

Senior lecturer, Nelson Mandela

Metropolitan University, Port Elizabeth

\section{SUMMARY}

The article traces the historical development of the legal concept of adoption from early civilization to present day South African law. The requirements and consequences of the practice of adoption changed with time, and with the waning of the popularity thereof, adoption as a legal concept was unknown in Roman-Dutch law - the common law of South Africa .During the early 1900's increasing numbers of informal "adoptions" taking place in South Africa led to the promulgation of the Adoption of Children Act 25 of 1923. Where conducive to the welfare of the child, adoption was permitted. However, the political ideology of the time in South Africa had a major influence on adoption as a legal institution, with the consequence that the considerations of the welfare of the child were superseded by the ideology of racial segregation. Post constitutional democracy led to the securing and protecting of basic human rights, not least of all within the private context of "family". Ratification of international instruments which made provision for adoption, together with the dawning of the constitutional era in South Africa saw the child as the bearer of his or her own rights. In terms of our Constitution, every child was guaranteed the right to family care or parental care or appropriate alternative care. The article focuses on the development and evolution of adoption to its present-day status.

\section{$1 \quad$ INTRODUCTION}

The long history of adoption as a legal institution makes it apparent that it is not a modern usage. As old as humankind, adoption was first practised on an informal basis. With time, laws were developed to regulate adoption. Adoption is found in the writings of the Greeks, Egyptians and Romans. In Roman times, adoption was practised frequently, largely to provide a solution in the cases of sterility and of frequent deaths in a family, and also to enable those who did not have a natural child of their own to acquire a child considered their own. Adoption was popular in Roman times and features strongly in the royal bloodlines of Rome. Likewise, ancient Egyptian society was structured around the family unit and the purpose of marriage was procreation and maintaining the family. Fertility was very important to the ancient Egyptians and children were considered a blessing. In Egypt, adoption was known and was mainly practised when a child was orphaned. In this instance, those who could not have children would adopt an orphaned child as their own. Forms of adoption were also used in ancient civilizations such as the ancient Japanese Shinto religion, which had its beginnings 
around $500 \mathrm{BC}$ or even earlier. References to adoption can also be found in early Hindu scripts that can be traced to the Vedic ages.

Some of the earliest written references to adoption can be found in the Bible in the story of Moses. ${ }^{1}$ According to the New Testament, Jesus was adopted by Joseph, the carpenter. When Mary married Joseph, he accepted Jesus as his own. In the New Testament, Paul makes use of the term for adoption five times in his letters to the Ephesians. ${ }^{2}$ The term used in the New Testament when referring to adoption is the Greek word "huiothesia". Further consideration of the historical development of the concept of adoption reveals that despite many changes within society over time, the practice of adoption remained in use consistently in one form or another. Suffice it to say, adoption is not an innovation of modern society.

The aim of this article is to consider adoption in South Africa from an historical perspective with a brief exposition of the international instruments and concomitant resolutions and guidelines that have been formulated relevant to adoption and alternative care of vulnerable children. Although the focus of the current research project is on modern-day intercountry adoption, it remains important to establish the historical context of the institution. The common law of South Africa is Roman-Dutch law and it is thus necessary to first provide an overview of adoption in both Roman and Roman-Dutch law. Thereafter, an outline of South African legislation regulating adoption is presented. Although South African law has been influenced in various significant respects by English law, it did not influence the law of adoption, and the common law of adoption remained Roman-Dutch law. In 1923 the Adoption of Children Act ${ }^{4}$ was adopted. Provision was made for adoption as a legally recognized institution, allowing for such adoption to take place where it was in the interests of the child concerned. The Adoption Act was superseded first by the Children's Act 31 of 1937, followed by the Children's Act 33 of 1960, Children's Amendment Act 50 of 1965, Child Care Act 74 of 1983 and finally the Children's Act 38 of 2005. With a view to strengthening and increasing its international commitments, a post-democracy South Africa has become party to a number of international instruments.

\section{ROMAN LAW}

\section{Introduction}

Although the origins of Rome prior to $450 \mathrm{BC}$ are unsure and largely based on speculation, ${ }^{5}$ it is apparent that adoption was practised in Roman times virtually from its beginnings. ${ }^{6}$ The adoption practised was based on dynastic

\footnotetext{
As recorded in Exodus 2: 1-10 (King James Version).

2 Adoption references in the Bible are found at Romans 8:15; Romans 8:23; Romans 9:4; Galatians 4:5; and Ephesians 1:5 (King James Version).

3 The meaning of this word is "to place a son".

25 of 1923.

Benet The Character of Adoption (1976) 22.

6 Boberg The Law of Persons and the Family (1977) 350; Du Bois (ed) Wille's Principles of South African Law 9ed (2007) 193; and Ferreira Interracial and Intercultural Adoption: A South African Perspective (LLD Thesis, UNISA 2009) 29.
} 
adoption, ${ }^{7}$ which has as its purpose the need to provide the family with an heir. Adoption played an important role in Roman times, both as a means to continue the family name and unit, as well as the importance accorded to the preservation of the domestic deities. ${ }^{8}$ The institution of adoption in Roman law was developed specifically as a means of acquiring an heir and successor to maintain the family name. ${ }^{9}$ Thus the relevance and focus of adoption were in relation to serving the needs of the family. In early Roman law, a man was not regarded as an individual, but rather as a member belonging to a particular group, with the family being the smallest recognized group. A family grouping consisted of those persons united through agnatic ${ }^{10}$ ties of relationship, including collateral relatives of every paterfamilias as well as their descendants. The Roman family formed a monocratic legal unit that consisted of the paterfamilias as the head and all persons who fell under the extensive power of the paterfamilias. This included his wife, if she was uxor in manu, ${ }^{11}$ as well as his children who had not passed out of his paterfamilias, and also his bondsmen and slaves. The family unit also formed a religious entity that together worshipped deities of the particular household. ${ }^{12}$ In Rome, the perpetuation of the family name and unit as well as the preservation of the cult of the domestic deities was of great importance. Where the family did not have its own heir, adoption was a means to acquire one.$^{13}$ Adoption was thus an important option to a family, particularly one of influence, as an heir was essential to carry on the family name. This was commonly used as a stratagem by the Roman aristocracy in early Roman law, with the focus being primarily to serve the family's needs, whilst the needs of the adopted person were considered less important. However, in later Roman times, during the reign of Emperor Justinian, ${ }^{14}$ an important change in public policy became apparent, and for the first time, the needs and interests of the adopted person were taken into consideration.

Two distinct forms of adoption were recognized in Roman law, namely adrogatio and adoptio. ${ }^{15}$ In both instances, the adopted person fell under the patria potestas ${ }^{16}$ of the person adopting. Adrogatio and adoptio differed from

\footnotetext{
Ferreira Interracial and Intercultural Adoption 29.

Kaser Romisches Privatrecht (Roman Private Law translated Dannenbring) 2ed (1968) 261. Van Zyl History and Principles of Roman Private Law (1983) 92.

10 Agnatic ties are those that exist between two persons where it is possible to trace a connection to a common male ancestor.

11 Meaning as the wife passes into the potestas of her husband, she is not an agnate of her own children. She only becomes an agnate of her children if, in consequence of her marriage, she passes into the manus (patria potestas) of her husband, and is thereby united with her children under the same patria potestas. A wife in manu is legally speaking the sister of her children. As a wife falls under the general power her husband held over the family, she too is seen as a member of her husband's household. She holds the position of familiaefamilias loco.

12 Kaser Romisches Privatrecht 50.

13 Kaser Romisches Privatrecht 261.

14 Sixth Century AD.

15 Schulz Classical Roman Law (1951) 143; and Sohm The Institutes of Roman Law tr Ledlie 3ed (1907) 479.

16 The adoptive parent acquired an almost unfettered power - the right of life and death, the
} so-called patria vitae necisque. 
each other significantly, both in form as well as function. ${ }^{17}$ Both were popular and widely practised. ${ }^{8}$ Through adoption, the adopted person became the filius $^{19}$ of the adoptive person and all relationships with the former family of the adopted were terminated. The aim of both adrogatio and adoptio was to confer the adopted person with the same rights and responsibilities as a person would have had as the birth child of the adopter. The adopted person's own persons who fell under his power, as well as all his property passed to the new paterfamilias. ${ }^{20}$ This in effect meant that where the adopted person had any person or persons under his own power, these person or persons were in effect now also under the power of the new paterfamilias. Adoption is found in the writings of the Greeks, Egyptians and Romans. ${ }^{21}$ Roman mythology refers to the legend of Romulus and Remus, who were saved from drowning after being abandoned in a basket on the banks of the River Tiber. According to mythology, the twins were found by a she-wolf who suckled them and they were fed by a woodpecker. A shepherd and his wife came upon the twins and fostered them to manhood. ${ }^{22}$ Romulus is given credit for founding Rome and he went on to become king in 735 BC. In Roman times, adoption was practised frequently, largely to provide a solution in the cases of sterility and of frequent deaths in a family, and also to enable those who did not have a natural child of their own to acquire a child considered their own. ${ }^{23}$ Adoption was popular in Roman times and features strongly in the royal bloodlines of Rome. Likewise, ancient Egyptian society ${ }^{24}$ was structured around the family unit and the purpose of marriage was procreation and maintaining the family. Fertility was very important to the ancient Egyptians and children were considered a blessing. In Egypt, adoption was known and was mainly practised when a child was orphaned. In this instance, those who could not have children would adopt an orphaned child as their own. ${ }^{25}$ Forms of adoption were also used in ancient civilizations such as that which practised the ancient Japanese Shinto religion, which had its beginnings around $500 \mathrm{BC}$ or even earlier. References to adoption can also be found in early Hindu scripts that can be traced to the Vedic ages. The adoption of a person previously sui iuris ${ }^{26}$ was known as adrogatio, whilst the adoption of a person alieni iuris ${ }^{27}$ was referred to as adoptio. $^{28}$

17 Buckland A Textbook of Roman Law 2ed (1932) 121; and Ferreira Interracial and Intercultural Adoption 15.

8 Boberg The Law of Persons and the Family 350.

19 Meaning the child (son) of the person concerned.

20 Kaser Romisches Privatrecht 262.

21 The Selective Voet being the Commentary on the Pandects of Johannes Voet Books I-IV tr Gane (1955) 142

22 Benet The Character of Adoption 22; and Van Zyl History and Principles of Roman Private Law35.

23 Voet The Selective Voet 142

24 Egyptian civilisation coalesced around $3150 \mathrm{BC}$ according to University College London "Chronology" (2000) http://digitalegypt.ucl.ac.uk/chronology/index.html (accessed 2013-1112).

25 Parsons "Old Age in Ancient Egypt" www.touregypt.net (accessed 2013-11-12).

26 The meaning of this word is an independent person.

27 The meaning of this word is a dependant or a subordinate member of the family. G.1.48. as referred to in Buckland $A$ Text-Book of Roman Law 101.

28 Buckland A Text-Book of Roman Law 121. 


\section{Adrogatio}

Adrogatio was the earlier form of adoption and was popular during the period pre-dating $450 \mathrm{BC}$ and the time of the Law of the Twelve Tables. ${ }^{29}$ Adrogatio was a legislative act, but no formalistic legal rules existed to effect adrogatio. ${ }^{30}$ In this instance, the adopting parent acquired patria potestas of another who was sui iuris. ${ }^{31}$ The relationship that the sui iuris had with his former family was terminated through adrogation and in effect reduced an independent person to a filiusfamilias. ${ }^{32}$ Adrogatio brought the adrogatus completely into the family. ${ }^{33}$ As adoption brought paternal power into existence, a woman was automatically disbarred from adopting. ${ }^{34}$ The adoption was subject to the approval of the popular assembly. It was considered unconstitutional to deprive a person of either his franchise or domestic independence without his consent. A motion for this purpose was brought before the comitia curiata. ${ }^{35}$ In early Roman civilization, little distinction was made between legal and religious rules and those called upon to expound and advise upon the rules were the priests who were officially appointed - namely the pontiffs. The advice was given by a pontiff in terms of his official position and was not done informally. In the case of adoption, it appears as though the pontiff was called upon to decide on the material facts before him as to whether adoption was permissible in a particular instance. ${ }^{36}$ Under the influence of Diocletian, a new form of adrogatio took place. This procedure took place before the emperor, who was Pontifex Maximus (the supreme pontiff), who then conferred the decree of adrogatio by means of an order known as the rescriptum principis. ${ }^{37}$

Over time, the function of the comitia became a mere witnessing of the act. No formal legal rules regulated adoption, which was based on the legislative act of approval of the popular assembly only. Eventually, it became a discretionary decision taken by the emperor of the time. The decree of comitia had become a mere formality of the popular assembly, although it had originated as a legislative act. ${ }^{38}$ The comitia was sovereign. ${ }^{39}$ Adrogatio could only be affected in the city of Rome, since the popular assembly could only be held here and could only be affected on two days of

\section{Lex Duodecim Tabularum.}

Schultz Classical Roman Law 144.

31 This term signified an independent person. G.1.99-107; and Buckland A Text-Book of Roman Law 124.

32 This term signified a dependent status, in the context of sonship in a family.

33 Buckland $A$ Text-Book of Roman Law 125.

34 Schulz Classical Roman Law 144; Buckland A Text-Book of Roman Law 123; and D.1.7.40.1.

35 Kaser Romisches Privatrecht 261; and Schultz Classical Roman Law 144.

36 Buckland A Text-Book of Roman Law 124; and Sohm The Institutes of Roman Law 479.

37 The meaning hereof is imperial rescript. The formula ran as follows: "velitis iubeatis, uti L.Titio tam iure legeque filius siet, quam si ex eo patre matreque familias eis natus esset, utique ei vitae necisque in eum potestas siet, uti patri endo filio est, haec ita ut dixit, ita vos Quirites rogo". Kaser Romisches Privatrecht 261; Schulz Classical Roman Law 148; and Sohm The Institutes of Roman Law 479. 
the year - namely, 24 March and 24 May, when the comitia convened for this purpose. ${ }^{40}$ With adrogatio it was essential that the adopted person renounce his former domestic cult. Although it appears as though the consent of both the adoptive parent and the adopted person was required, ${ }^{41}$ they were not required to be present during the procedure, nor was their need to consent legislated. ${ }^{42}$ Schulz states that where parties were living in another province, they could apply to the pontiff by letter or by a deputy and adrogatio could be effected, since the presence of the parties to the adrogatio was not required. ${ }^{43}$

The consequence of such a decree meant that the relationship between the former family and the filius was terminated legally, and a new legal relationship between the filius and the adoptive parent was created. ${ }^{44}$ Thus, adrogatio had a far-reaching impact on both the adopted person and all his descendants. ${ }^{45}$ The effect of adoption was accordingly that the adoptatus ${ }^{46}$ was removed from the potestas of one and placed under that of another. The cognatic blood tie ${ }^{47}$ was not affected by adrogatio ${ }^{48}$ and although the adoptatus acquired the rights of a natural son through the procedure, these rights were dependent on the agnatic tie. ${ }^{49}$ Adrogatio had the effect that the adopted person was brought completely into the family of the adrogatus, ${ }^{50}$ and the adrogatus brought with him all of those under his potestas ${ }^{5}$ at the time of adoption. ${ }^{52}$ Women at first could not be adrogated, as women could not appear before the comitia curiata, but this disappeared when adrogation by imperial rescript took place. Furthermore, as women did not exercise parental power, they were incapable of adrogating, but they were permitted to establish the same legal relationship with an adopted child as a mother had with her natural child by quasi-adrogatio. In addition, an impubens ${ }^{53}$ originally could not be adrogated, but the emperor Antoninus Pius permitted such adrogation under certain circumstances.

\footnotetext{
Ibid.

Buckland A Text-Book of Roman Law 127

Schulz Classical Roman Law 144-145.

Schulz Classical Roman Law 146.

4 Buckland refers to the following: "adrogatio destroyed a family and thus was only allowed to save another ie to provide a heres" in A Text-Book of Roman Law 125.

45 Thomas Textbook on Roman Law (1976) 437-438 refers to G.1.107; D.1.7.15 and Inst.1.11.11; Buckland A Text-Book of Roman Law 125; and Van Zyl History and Principles of Roman Law 92.

46 The word translates into the adopted child.

47 A cognate tie is a mode of descent where all descendants of an apical ancestor through any combination of male or female links are included. Cognates are therefore those persons who are related through consanguine ties on either the mother's or father's side. On the other hand, agnatic ties are those descendants related though a male link. Such relationships are exclusively through the male line or patrilineal descent. In Roman law, agnati were those relatives who could trace their kinship to a common male ancestor.

48 Buckland A Text-Book of Roman Law 122.

49 Sohm The Institutes of Roman Law 479.

50 Schulz Classical Roman Law 124.

1 Buckland A Text-Book of Roman Law 125

2 Sohm The Institutes of Roman Law 480.

53 The meaning of this word is youth below the age of puberty.
} 
Adrogatio was restricted and was only allowed as a means of last resort to a family who had no successor. Where a family already had a child, the adrogatio, when allowed, was allowed once only. ${ }^{54}$ The adopter had to provide sound reasons for adrogatio and the impubens was thus protected against any disadvantages that might result from his adoption. Furthermore, the adoptandus ${ }^{56}$ had to be at least 18 years older than the adoptatus. ${ }^{57}$ Adrogatio underwent certain changes over time, but it retained its essential character throughout the development of Roman law. This form of adoption was frequently practised by influential families to secure an heir and successor to the family name. An example is found where Octavius (later known as Emperor Augustus) was adrogated by Julius Caesar after his death in $44 \mathrm{BC}$. When Julius Caesar died, he did not have a natural heir, although he had made moves to establish his nephew, Octavius, as his successor. The process was not completed before his demise, but Caesar had stated his intention in his will. Octavius was adopted posthumously through the process of adrogatio.

\section{Adoptio}

Adoptio as an institution developed later than adrogatio and was based on certain principles in the Law of the Twelve Tables ${ }^{58}$ and the rules of the ius civile, which provided that where a son was sold three times, he would be freed from his natural father's potestas. ${ }^{59}$ Adoptio was the procedure recognized to adopt a dependent person. The act of adoption was artificial and formalistic and was not legislative in nature.

Adoptio took place in two stages, consisting firstly of the preliminary sales followed by the act of adoption. The preliminary sale or sales had the effect of destroying the potestas that a father had over his son, who was alieni iuris, and these sales were followed by a repeated sale. This was a transaction that was based on the rule of the Law of the Twelve Tables. It was essential to the adoption that the patria potestas be abolished. ${ }^{61}$ The first sale would take place to the confidant, who could be the adopter himself. The confidant or adopting person would free the son who would then revert to the potestas of his natural father. The second sale then took place with the confidant or adopting person, and again the confidant (or adopting person) would free the son. The third sale had the effect that the bondage that the natural father had over his son was destroyed. ${ }^{62}$ If the sale had been to a confidant, the prospective adopter would bring a collusive

\footnotetext{
Buckland A Text-Book of Roman-Law 126.

Sohm The Institutes of Roman Law 481.

The meaning of this word is the adoptive parent.

The meaning of this word is the adopted child.

58 A comprehensive collection of rules framed by the officers called the Decemviri. These men were especially appointed for this purpose.

59 Buckland A Text-Book of Roman Law 121; G.1.98,99; Ulp. 8. as referred to in Buckland A Text-Book of Roman Law $121 \mathrm{fn} 11$; and Sohm The Institutes of Roman Law 480

60 Schulz Classical Roman Law 146.

61 Ibid.

62 Sohm The Institutes of Roman Law 480
} 
action against such confidant, claiming that the son was his. The claim by the adopting father against the natural father that the filius was his son is the act of adoption. There was no defence against this claim and the judgment went accordingly. ${ }^{63}$ The transferral of the son was through formal mancipatio. The consent of the filius was not required. ${ }^{64}$ Once the adoption process was completed, the adoptive son, (based on his agnatic tie to the adopter), acquired the same rights as that of a natural son, to the adopter. ${ }^{65}$ The cognatic tie was not affected. ${ }^{66}$ Any children that the adopted son may have had prior to the third sale remained in the potestas of the natural father of the adopted son, whilst those conceived after the third sale fell to the new family.

During the period of Justinian, significant changes were effected in respect of adoption. Although the fictitious sales were dispensed with as useless, their essence was preserved. ${ }^{67}$ The former procedure was abolished and replaced by a far simpler one. The original father, as well as the adoptive parent and the alieni iuris, would appear before the magistrate. The original father would express his desire to give up his son for adoption, and the adoptive parent would declare his desire to adopt the son as his own. The transaction of adoptio was then entered on the acta of court. ${ }^{68}$

Adoptio plena and adoptio minus plena were recognized. ${ }^{69}$ In the case of the former, the filius remained in the potestas of his natural father and did not pass into the potestas of the adoptive father, ${ }^{70}$ thus retaining his rights of succession in his old family and acquiring rights only to intestate succession in his new family. ${ }^{71}$ Justinian remarked that an adoption taken lightly might be lightly ended so that the child would be in neither family. Adoptio plena ensured that the rights to succession in the adopted person's old family would be retained, and only rights of intestacy would be required in the new, with no right of complaint, should no provision be made for the adopted person in his adoptive father's will. Adoptio plena was an exception to the rule and this occurred where the old law of adoption applied. It took place where the adopting father was a natural ascendant - for example, where the grandson was given into adoption to his natural grandfather. It is not shown that potestas passed. ${ }^{72}$ Furthermore, it is not clear whether the consent of the adrogatus was required in classical law, but it certainly was not required in early Roman law.

Justinian was also responsible for the introduction of the rule that the adoptive parent had to be at least 18 years older than the adopted filius. The principle of this was that the adopter had to be old enough to be the father of

\section{Ibid.}

Buckland A Text-Book of Roman Law 127.

Buckland A Text-Book of Roman Law 122.

Ibid.

67 Lee An Introduction to Roman-Dutch 3ed (1931) 42; Gr.1.6.1. Van Leeuwen, 1.13.3; Voet, 1.7.7.; and Robb v Mealey's Executor (1899) 16S.C.133.

68 Buckland A Text-Book of Roman Law 123; and Sohm The Institutes of Roman Law 480.

69 Voet The Selective Voet Book I Title 7 143; and Sohm The Institutes of Roman Law 481.

70 Inst.1.11.2; C.8.47.10 as referred to in Buckland A Text-Book of Roman Law $123 \mathrm{fn} 5$.

Sohm The Institutes of Roman Law 480.

72 C.8.47.10.4, as referred to in Buckland A Text-Book of Roman Law $123 \mathrm{fn} 7$. 
the filius. Where the adoptive parent was not a natural ascendant, the effect of the adoption was limited in an attempt to protect the adoptans. This adoption was referred to as adoption minus plena which had the effect that the adopted filius remained in the patria potestas of the original father. The practice of adoption was common late in the Republic and early in the Empire. Diocletian extended the rule of adoption in 291 AD, allowing a woman to adopt where she had lost her natural children. Justinian accepted this rule as a general practice where the Emperor had given his permission.

It is apparent that throughout the development of adoption in Roman times, the focus was more on the interests of the adoptive parent than those of the child; the child's interests were of secondary importance.

\section{ROMAN-DUTCH LAW}

South African common law evolved essentially from three countries. Our law had its origins in Roman territory for a thousand years prior to $535 \mathrm{AD}$, in the Netherlands for centuries prior to the $19^{\text {th }}$ Century, and in South Africa from 1652. Roman-Dutch law is a fusion of Roman principles and early law from the Netherlands; these laws form the core of our common law today (with English law as a lesser influence).

The popularity of adoption waned over time and was not formally practised in Roman-Dutch law. ${ }^{73}$ The Roman-law principles of adoption were not incorporated into Roman-Dutch law. The concept of patria potestas was foreign to Roman-Dutch law and, although there are no formal references to adoption, it is quite plausible that informal adoptions took place. However, no legal consequences arose from such informal agreements and, in the eyes of the law, the child remained the child of the original family. Parental power could not be transferred from the natural parent to another through adoption. Van Leeuwen states:

"the adoption of children as it existed among the ancients is unknown and not practised among us, although children adopted i.e. taken into our family and educated by us may, like other persons, be instituted our heirs, without, however, our being obliged to do so: but, unlike children or blood relations, they cannot inherit ab intestato".

Friesland was an exception to the rule. ${ }^{75}$ Voet states that it seems as though adoption still existed in Friesland as the statute regulating adoption was never per se abolished. ${ }^{76}$ Whether adoptions did in fact take place has been open to question. ${ }^{77}$

73 Gr.1.6.1; Van Leeuwen, 1.13.3; Voet, 25.7.6.; Van der Linden 1.4.2. (as referred to in Lee 42 fn 4) and Boberg The Law of Persons and the Family 350; Wille's Principles of South African Law 193; and Voet The Selective Voet Book 1 Title 7143.

74 Van Leeuwen in Gotnm(as translated by Kotze) vol.1.87.

75 Boberg The Law of Persons and the Family 350 fn 2; Grotius Inleidinge 1.6.1; and Voet Commentarius 1.7.11.13.

76 Voet Commentarius1.7.7.

77 Studiosus "Die Aard van die Gesagsregte van Ouers ten opsigte van hul Minderjarige Kinders" 1946 THRHR 45. 


\section{SOUTH AFRICAN LAW}

\section{Introduction}

Although informal adoptions would have taken place in South Africa, adoption as a legal act was unknown before 1923. These informal adoptions generally took place by private agreement between parties. ${ }^{78}$ In terms of our common law, where parents informally agreed to give custody and control of their child to another, such agreement was of no force and effect. ${ }^{79}$ Such an "underhand" or "private" adoption could not be enforced and created no legal relationship between the adoptive parents and the child concerned. Adoption as a legal act, creating a legal relationship between a parent and a child, was unknown to the (then) Cape of Good Hope. This position was confirmed in Robb $v$ Mealey's Executor, ${ }^{80}$ where the court held that adoption was not recognized as a means of transferring parental power from the natural parent to another person.

"It is a factual objection to this contention that the law of the colony does not recognise adoption as a means of creating the legal relationship of a parent and the child.

Under the Roman law, this relationship was created but Roman-Dutch law did not, in this respect, follow the Roman law. Innes QC argued (was he counsel?) that "there is no machinery for adoption in the Roman-Dutch law or in Cape law". ${ }^{82}$ The court pointed out that there was no machinery for adoption in the Cape Colony, and that the positive law of the time did not recognise adoption as a means of creating a legal relationship of parent and child. Such a relationship was established only between a natural parent and a child.

The need for legislated adoption became apparent during the early twentieth century. Adoption legislation was first enacted in 1923 in the form of the Adoption of Children Act, ${ }^{83}$ which recognized adoption as a means of legally creating the relationship of parent and child. At the second reading of the Adoption of Children Bill in the debates of the House of Assembly, one Mr R Feetham, a member of the House of Assembly, indicated that the proposed Bill was modelled on the New Zealand Infants Act. ${ }^{84}$ This contrasts with the suggestion by Rowland and Van der Merwe ${ }^{85}$ that the South African legislature was possibly influenced by English law. That view cannot be correct, since the English Adoption of Children Act ${ }^{86}$ (England's first piece of legislation concerning adoption) was enacted in 1926; three years after the

78 Edward v Fleming (1909) TH 232 (testamentary provision); and Robb v Mealey's Executor supra 133-136 and contractually (Fibinger v Botha (1095-1910) 11 HCG 97).

Van der Westhuizen v Van Wyk 1952 (2) SA 119 (GW).

Robb v Mealey's Executor supra 133-136.

1 Ibid.

Robb v Mealey's Executor supra 135.

25 of 1923.

86 of 1908.

Van der Merwe and Rowland Suid-Afrikaanse Erfreg 6ed (1990) 83.

Adoption of Children Act of 1926. 
South African Adoption of Children Act came into existence. ${ }^{87}$ Ferreira $^{88}$ discusses this point and indicates that it appears that Van der Merwe and Rowland based their assumption on Wille's Principles of South African Law, ${ }^{89}$ where the authors indicated that the English law on adoption was almost identical to the South African law in this regard. Reference to the debates of the House of Assembly clarifies any misconception as to the origins of the Adoption of Children Bill.

\section{Legislation}

\section{Adoption of Children Act 25 of 1923}

The Adoption of Children Act ${ }^{90}$ was promulgated on 30 June $1923,{ }^{91}$ and the Act became operational on 1 January $1924 .{ }^{92}$ Adoption was thus legalized for the first time in South Africa. The absence of the institution of adoption in early South African law can be explained by the fact that Roman-Dutch law, the South African common law, did not recognize the legal concept of adoption, and English law also had no influence on South African law in this regard. ${ }^{33}$ Prior to this Act, adoption of a child took place by private arrangement. ${ }^{94}$ South Africa's adoption legislation was therefore based on neither Roman-Dutch nor English law but, as already mentioned, was based on legislation originating in New Zealand. At the second reading of the Bill, $\mathrm{Mr}$ Feetham presented and explained the need for the formalization of adoption in South Africa. ${ }^{95}$ The need for the formalization was based on the increasing number of informal adoptions taking place in the Cape Colony. Private adoptions were not recognized as having legal consequences and, as a result, no legal parent-child relationship arose between the child and the prospective adoptive parent. The legal relationship of the natural parent and the child remained intact. As an informal adoption led to insecurity of position for prospective adoptive parents, many shied away from adopting a child, which then led to the child being brought up in a state institution instead of in a family environment. ${ }^{96}$

The main objective of this Act was to formulate the legal requirements to sever the existing legal bond between a child and its natural parents or guardians, and create a new relationship between the adoptive parent and

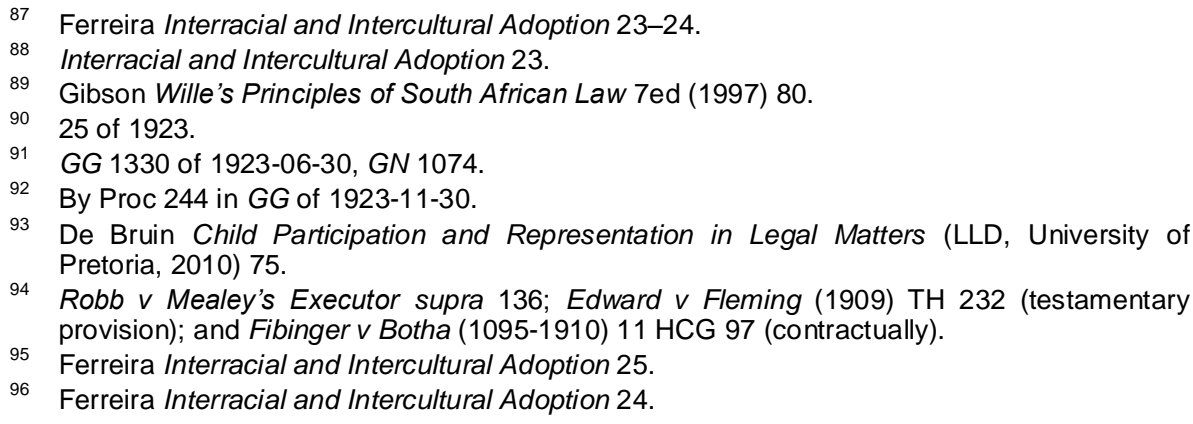


the child. ${ }^{97}$ Only adoption was regulated by this Act. The Act made provision for the adoption of a child subject to the provisions of the Act and the confirmation of adoption by a magistrate. The core policy was that adoption was allowed where it was in the interests of the child and in order to promote the welfare of the child. ${ }^{98}$ The Act provided that, before making an order for adoption, the magistrate had to be satisfied that the person proposing to adopt a child was of good repute and that he or she was a fit and proper person to be entrusted with the care and custody of the child. ${ }^{99}$ Such prospective adoptive parent/s had to be able to bring up, maintain and educate the child sufficiently. ${ }^{100}$ The main objective of the act of adoption was to promote the welfare of the child; an application for adoption would only be confirmed where the magistrate was of the opinion that the interests and welfare of the child would be promoted. ${ }^{101}$ Where an order for adoption was made, the adopted child would legally be deemed to be the child born of lawful wedlock of the adopting parent.

There was no explicit ban on interracial and inter-cultural adoptions in this Act, but it is submitted that the racial consciousness of the day was so deeply entrenched that a legislative bar was not necessary. ${ }^{103}$ Joubert ${ }^{104}$ submits that no formal interracial adoptions are known to have taken place, and although there were no legal provisions prohibiting such adoptions, "it can be accepted that such adoptions would have run contrary to the accepted social views of the time". ${ }^{105}$ This too is the view of Mosikatsana ${ }^{106}$ who opines that racism was so firmly rooted in the national psyche that it was felt that there was no need for legislative intervention. It can accordingly be assumed that the legislature did not contemplate that anyone would wish to adopt a child that differed from them in race and/or culture.

The Adoption of Children Act was repealed and replaced by the Children's Act of $1937 .{ }^{108}$

\section{Children's Act 31 of 1937}

The Children's Act was assented to on 13 May $1937^{109}$ and came into operation on 18 May 1937. This Act repealed the Adoption of Children Act. The basic policy of permitting adoption where it was conducive to the welfare

97 Joubert "Interracial Adoptions: Can we Learn from the Americans?" 1993 SALJ 726; and De Bruin Child Participation and Representation in Legal Matters 75 fn 92.

8 S 4(1).

$99 \mathrm{~S} 4(1)(\mathrm{c})$.

100 S $4(1)(c)$.

101 De Bruin Child Participation and Representation in Legal Matters 75

102 S 8(1)(a).

103 Zaal "Avoiding the Best Interests of the Child: Race-matching and the Child Care Act 74 of 1983" 1995 SAJHR 374.

104 Joubert 1993 SALJ 726.

105 lbid.

106 Mosikatsana "Transracial Adoptions: Are We Learning the Right Lessons from the Americans and Canadians? A reply to Professors Joubert and Zaal" 1995 SALJ 607.

107 Ferreira Interracial and Intercultural Adoption 26-27.

108 Act 31 of 1937.

109 The Afrikaans text was signed by the Governor-General of the time. 
of the child was retained in this Act, although the scope of the Act was much broader than its predecessor. Provision was made for all matters relating to children and not exclusively for matters relating to adoption. The provisions relating to adoption were contained in Chapter VII. In terms of this Act, a child up to the age of 19 years remained eligible for adoption ${ }^{110}$ on condition that the proposed adoption would serve the interests of the child and furthermore was conducive to the welfare of the child. ${ }^{11}$

The new Act was also responsible for the establishment of children's courts. Since their establishment, all adoption applications have been considered by the Children's Court in the area in which a child resides. The Children's Court is a district court. Giving jurisdiction to a district court to hear matters that relate to adoption is contrary to the general rule that all matters that have an effect on status are to be heard by the High Court. ${ }^{12}$ In $A D \vee D W,{ }^{113}$ the Constitutional Court held:

"With or without the necessary information, the High Court was correct in holding that the appropriate route for the proposed intercountry adoption was

to bring the proceedings for adoption in the Children's Court.

It cannot be argued that adoption does not have a profound effect on status, and it may even be argued that adoption has a more profound impact on status than any other legal action or application. However, the Constitutional Court has considered this issue on two occasions and in both instances found that the Children's Court was the correct forum to make orders of adoption. ${ }^{115}$ An adoption could be granted on application to the Children's Court in the district in which the child concerned resided. ${ }^{116}$ No specific provision was made in the Act requiring the consideration of race or culture of the parties, and thus theoretically interracial or inter-cultural adoption was not prohibited. ${ }^{117}$ However, given the social views of the day, it is unlikely that interracial adoptions would have taken place. According to Mosikatsana, it appears that no such adoptions were confirmed, ${ }^{118}$ notwithstanding the fact that they were not expressly prohibited. ${ }^{119}$ As referred to above Mosikatsana bases the omission by the legislature on the racial and political trend in South Africa at the time. Racism was already firmly established in the nation at the time, and there was thus no need for legislative intervention in this regard. ${ }^{120}$

The Children's Act of 1937 was repealed by the Children's Act of 1960.

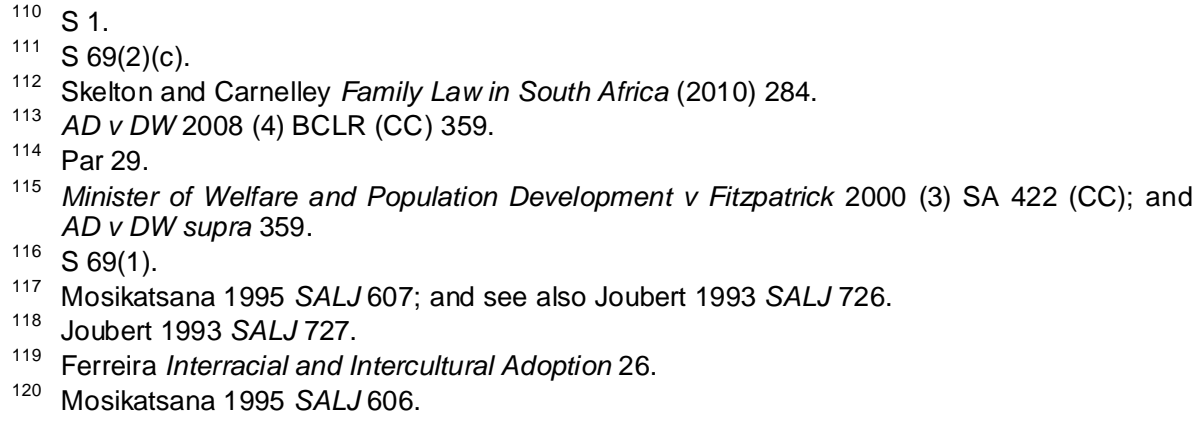




\section{Children's Act 33 of 1960}

\section{(i) Introduction}

The Children's Act 33 of 1960 was assented to on 7 April 1960 and came into operation on 14 April $1960 .^{121}$ Some changes were made to the existing law in South Africa relating to adoption, but the basic policy of its predecessor was retained - namely, that adoption was to be considered where it was in the interests of the child and where it would be conducive to the welfare of the child. The scope of this Act was wider in its application and made provision for a variety of issues with respect to children - inter alia, the appointment of commissioners of child welfare, the establishment of children's courts and the adoption of children. The aim of the Act was to promote the welfare of the child by admitting him or her to an authentic family while at the same time safeguarding the interests of his or her natural and prospective parents.

\section{(ii) Qualifications of adopting parent}

In his or her application to the commissioner, an applicant wishing to adopt a child had to satisfy the commissioner that he or she was a person of good repute and was a fit and proper person to be entrusted with the custody and care of the child concerned. Furthermore, he or she had to have adequate means to maintain and educate the child. ${ }^{122}$ Besides the technical requirement for the prospective adoptive parent to be a South African citizen, section 72 provided the only attempt by the legislature to define the qualifications for a parent. The role of the social worker was important in terms of the Act in this regard. It was apparent that the social worker concerned was expected to undertake a thorough investigation into the background of the natural parents, the child and the prospective adoptive parent or parents. The assessment of the suitability of a particular applicant weighed heavily with the commissioner tasked with making a decision on adoption.

\section{(iii) The issue of race}

The then deputy Minister of Education, Science and Social Welfare and Pensions, Mr BJ Vorster, initiated the publication of clause 1(x)(j) of the Children's Bill of 1960. Indicative of the political ideology on race at the time are the provisions in the Children's Amendment Act which defined a "Black person" in section 1 and furthermore provided for the definition of a "Black Children's Court". Also introduced was the provision that Black persons living together in terms of a customary union could adopt a child.

Read together with section 35(2), this clause would have had the effect that a child could be forcibly and permanently removed from his/her family. Such removal would have been based solely on the fact that the race of the

121 The Afrikaans text was signed by the Governor-General appointed at the time.

122 S 71(2)(b). 
family members and the child differed. This mandatory termination of a parent-child relationship was in line with the existing political ideology in South Africa and the existing race-conscious legislation - inter alia, the provisions of the Immorality Act ${ }^{123}$ which prohibited sexual relations across racial lines. Concern that this clause would lead to much international criticism led to its withdrawal before its enactment. Despite the withdrawal of the proposed clause, the approach of the Government to interracial adoptions was clear. The ideology of race segregation superseded the considerations of the child.

Although nowhere is interracial adoption prohibited in Chapter VII of the Act, section 35(2) was an indication of the intention of the legislature. This section read as follows:

"In selecting any person in whose custody a child is to be placed, regard shall be had to the religious and cultural background and the ethnological grouping of the child and, in selecting such a person, also to the nationality of the child and the relationship between him and such person" "24 (author's own emphasis).

The meaning and extent of "regard shall be had" was vague and uncertain and it was left to the judiciary to determine these issues. Rapid urban expansion and social integration in the 1960s led the existing apartheid Government to introduce legislation that provided for the segregation of the races. In keeping with this approach, the legislature included "race" as a consideration in the parent-child relationship for the first time. Certain terms were introduced into the Act to achieve this end - namely, the "culture" and the "ethnological grouping" of the adoptive parents and the adoptive child were deemed relevant. ${ }^{125}$ These terms first appeared in section 35(2), a section that later became section $35(2)(a) .{ }^{126}$ This was in keeping with the enactment of a series of measures introduced as a means to prohibit certain heterosexual transnational relationships between adults. ${ }^{127}$

In effect, section 35(2) was a modified version of the withdrawn clause of 1960. Read together with the proposed clause $1(x)(j)$, section 35(2) was clear: where the parent or family of a child was registered in the population register as classified under a particular race, and the race of the child differed from its family members, such child could be forcibly removed from

123 Act 23 of 1957.

124 This section later became s 35(2)(a) when ss 35(2)(b) and 35(2)(c) were added in the Children's Amendment Act of 1965. The subsections read as follows:

"(b) Any illegitimate child whose classification in terms of the Population Registration Act, 19509Act 30 of 1950), is the same as that of his mother shall be deemed to have the same religious and cultural background and nationality of his mother and only relatives of the mother of any such child shall be regarded as being related to such child.

(c) A child shall not be placed in the custody of any person whose classification in terms of the Population Registration Act, 1950, is not the same as that of the child 25 S 35(2). except where such person is the parent or guardian of the child."

126 This took place when ss 35(2)(b) and 35(2)(c) were added to the Children's Amendment Act 50 of 1965.

127 Immorality Act 5 of 1927 (renamed the Sexual Offences Act 23 of 1957). 
the care of its family. Race could effectively serve as a total bar on adoptions. Placement would have operatively been rendered impossible as such placement would have rendered the child ipso facto as a "child in need of care". ${ }^{12}$

Without clause $1(\mathrm{x})(\mathrm{j})$, section 35(2) was unclear. The provision stipulating that "regard shall be had" to the race, religion and culture of the child was confusing and ambiguous. To what extent did regard need to be had to these considerations, and, under what circumstances would a court or social welfare worker treat the difference in race, culture or religion as a bar to (transracial) adoption? Spiro ${ }^{129}$ interpreted this to mean that a child might not have been adopted where the race of such child differed from that of the adopting person, unless he or she was the natural guardian or custodian of the child. Where the child was illegitimate and classified as belonging to the same race as his natural mother, the child was deemed to be of the same religion, nationality and cultural background as his mother. ${ }^{130}$ The legal directive of section 71(1)(b), when incorporating the provisions of section $35(2)(b)$, created the legal basis of the so-called "matching like to like" and resulted in an extensive set of criteria to which "regard need be had" by social workers involved in adoption matters. ${ }^{131}$

Boberg ${ }^{132}$ notes that it appeared that even "physical likeness" played a role in selecting potential adoptive parents. Referring to "A Guide to Adoption Practice" 133 he takes note of the approach that "even physical likeness of the child to his proposed parents is considered relevant, though not decisive"! ${ }^{134}$ The interpretation of section 35(2) remained ambiguous. Whatever approach was taken to section 35(2), it was clear that the provision was opposed to a transracial placement.

The Joffin case

Section 35(2) was first tested in the case of Joffin $v$ Commissioner of Child Welfare, Springs. ${ }^{135}$ The proceedings were initiated by way of review. The plaintiffs in the case requested that their names be placed on a waiting list to adopt in January 1962. They were married professional parties of good character and were followers of the Jewish faith. In August, 1962, an illegitimate child was born to a mother who belonged to the Protestant Christian Dutch Reformed Church. The natural mother gave the baby up for adoption and the plaintiffs had had continuous care of the child for the first 30 days from the child's birth. The child was in the care of the plaintiffs with the full consent of the child's mother. On their application to adopt the child, the commissioner of the Children's Court refused to confirm the application. The reason for the refusal was the vast difference in religious practices of

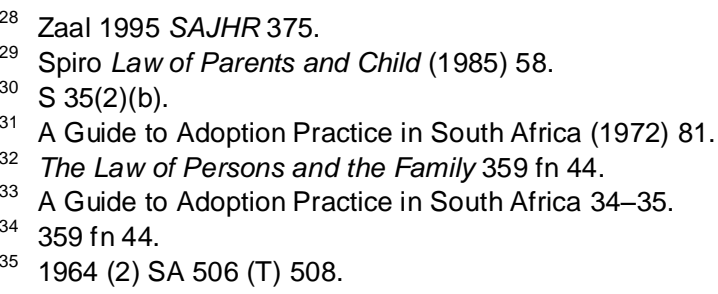


the parties; the natural mother belonged to the Christian Dutch Reformed Church whereas the prospective adoptive parents were followers of the Jewish faith. The court was called upon to decide whether the words "shall have regard to" in the Act were mandatory or whether the wording conferred a discretion on the court in making its decision.

The plaintiffs applied to the commissioner of child welfare (first defendant) to adopt the child in terms of section 10(4) of the Children's Act. The commissioner in the case was concerned that the vast difference in the religious backgrounds of the prospective parents and the child could prove an obstacle to the child's adoption. The child remained in the custody of the plaintiffs. In October 1963, the plaintiffs were informed that their application to adopt the infant had been refused. The second defendant, in whose jurisdiction the plaintiffs then resided, ordered the removal of the child from the plaintiffs' care on 1 October 1963. Application was made to the second defendant on 8 October 1963 for the plaintiffs to adopt the infant. The second defendant delivered an oral judgment on 30 October refusing the application. It was submitted to the court that the decision of the second defendant was based on the consideration of the facts of the particular case and that it had found that in this instance the court had no discretion in its application of section 35(2), read with section 71(b), given the differences that existed between the Jewish and Dutch Reformed faiths in the matter under consideration. The matter was taken on review on the basis that section 35(2) of the Act enjoined the Commissioner to consider the matters in section 35(2) and to exercise his discretion based on all the factors.

Section 71(1)(b) provided further and reads as follows:

"In considering any such application the children's court shall have regard to all the matters mentioned in sub-section (2) of section 35."

And section 35(2) provided:

"In selecting any person in whose custody the child is to be placed or any children's home, other than a children's home established in terms of sub-sec (3) of section 39, to which a child is to be sent, regard shall be had to the religious and cultural background and ethnological grouping of the child and, in selecting such a person, also to the nationality of the child and the relationship between him and such a person."

The plaintiffs contended that the only issue to be decided was whether the second defendant had discretion in terms of section 71(2)(a), read with section 35(2) of the Act after which the second defendant decided that he did not have the discretion. In the matter before the court, the plaintiffs contended that in so deciding, the second defendant was "not only wrong in law but also committed a gross irregularity which resulted in failure of justice and prejudice to the plaintiffs and the child."

In his consideration of the issue before the court, Ludorf $\mathrm{J}$ referred to the English decision of Illingworth $v$ Walmsey, where the court held that the words "regard shall be had to [the difference]" meant that the tribunal in question had to bear the difference in mind as a factor, but that the tribunal had a discretion in reaching its decision. Referring to the fact that each case had to be considered on its own merits, Ludorf $\mathrm{J}$ held that "it would be 
manifestly wrong and unjust for the children's courts to categorise prospective applicants in accordance with the cultural, religious (and linguistic) background of the parent and child."

Furthermore, in Perry $v$ Wright, the court held that similar words were "a guide, not a fetter".

Citing the cases as persuasive authority for his decision, Ludorf $\mathrm{J}$ concluded that the words "have regard to" were in fact not mandatory in their application. The court held that section 71(1)(b) softened section 35(2)(c) in that, where a decision of adoption was considered and it appeared there was a difference of religion, as in the case at hand, the tribunal should bear this difference in mind to exercise a discretion in regard thereto. Section 35(2) granted a discretion that should be exercised but was not mandatory in its application.

The review court set aside the commissioner's refusal to allow the Jewish couple to adopt the child concerned and the application by the plaintiffs to adopt the infant was granted. This approach to the interpretation of section 35(2) granted leeway to legally permit interracial adoptions. Although laudable, this approach did not take effect in practice. Once an adoption application was granted, the provisions of segregation laws would come into effect and bar persons of differing race classification from living together. The segregation laws of the day effectively prevented a child from being placed with foster parents of a different race classification before the adoption process was finalized. However, once finalized, the child could not be prevented from living with the adoptive parents.

To give effect to the legislative intention of the withdrawn clause $1(x)(\mathrm{i})$, the legislature published two further subsections to section 35(2) in 1965.

The Children's Amendment Act 50 of 1965

With the promulgation of the Children's Amendment Act of 1965 two subsections of these amendments, namely section 35(2)(b) and section 35(2)(c), had relevance to section 35(2) They provided as follows:

"(b) Any illegitimate child whose classification in terms of the Population Registration Act, $1950^{137}$ is the same as that of his mother shall be deemed to have the same religious and cultural background and nationality as his mother and only relatives of the mother of any such child shall be regarded as being related to such child.

(c) A child shall not be placed in the custody of any person whose classification in terms of the Population Registration Act, 1950, is not the same as that of the child except where such person is the parent or guardian of the child."

As a consequence of the above statutory conditions, it is evident that the classification of a child in terms of the population register played a decisive role in the placement of the child. Race became an overriding consideration in placements for adoption and in terms of section 35(2)(c). No child could

\footnotetext{
Children's Amendment Act 50 of 1965

137 Act 30 of 1950.
} 
be placed in the custody of a person who was classified as being of a different race.

The Children's Act made provision for the correction of obvious errors by the commissioner concerned when issuing the adoption order. ${ }^{138}$ The Supreme Court ${ }^{139}$ had the jurisdiction to review such instances to consider setting aside an order procured by fraudulent means, or granted without due compliance of the prescribed legal requirements.

The exclusion of a parent or guardian was considered as a means of defending the legislative position in South Africa in that humanitarian grounds had formed the basis for the parental-exception clause in interracial adoptions. Those who were aware of the full machinery of the Act were not fooled and the parental exception clause was treated as meaningless. The introduction of the terms "culture" and "ethnological grouping" left no uncertainty as to the intention of the legislature concerning the relevance of these factors in making a placement of the child. The Children's Amendment Act accordingly confirmed the approach to interracial and inter-cultural adoptions. In Ex Parte Kommissaris van Kindersorg: In Re $N L^{140}$ the Supreme Court considered the question on whether sections 35(2)(c) and 71(1)(b) should be read together as placing a blanket prohibition on interracial adoptions where the applicants were not the natural parents of the child concerned. In coming to its decision the court held that section 71(1)(b) of the Children's Act of 1960 had the effect that section 35(2)(c) of the Amendment Act could not be interpreted as meaning that a difference in race of the parties could lead to a total prohibition on interracial adoptions. Although the adoption order was confirmed in this instance notwithstanding the fact that the race of the applicant varied from that of the child, the decision did not mean that interracial adoption was now permissible. ${ }^{14}$ Zaal $^{142}$ and Ferreira ${ }^{143}$ have both expressed their doubt as to whether the decision changed the status quo as to interracial adoption.

The defenders of South Africa's image contended that the inclusion of the exception in favour of a child's parent or guardian meant that the legislature's intention was that a child's custody determination rested solely on the criterion of the best interests of the child. However, it is clear that this was not so when one has reference to other provisions of the Amendment Act. Section 35(2)(c) did not alter the legal position of the mother of the illegitimate child, as it was accepted that generally the mother would have been able to keep her child in her custody. However, the parental exception (when read in isolation) appeared to benefit the father of an illegitimate child - in that where the race of his child varied from his own official classification, a father might then be considered as the exception under section 35(2)(c). However, when read with section 35(2)(b), it is evident that the father did not classify as the exception to the bar in terms of the provision of section

\footnotetext{
S 71(8).

Not the Children's Court since it was functus officio

401979 (2) SA 432 (T).

141 Mosikatsana 1995 SALJ 609.

1921994 SAJHR 367-377.

143 Interracial and Intercultural Adoption 33.
} 
35(2)(c). Section 35(2)(b) provided that, where the child was illegitimate, only "relatives of the mother shall be regarded as being related to such child". When the legal provisions are read together, it is clear that the father of an illegitimate child was excluded from the parental exception. Furthermore, an admission of having had intercourse with a person of colour would have been an admission of guilt of a crime under the Immorality Act. $^{14}$

Section 71(1)(b) of the Children's Act dealt with adoption requirements and indicated that the court adjudicating the adoption should have regard to the provisions of section 35(2), which were inclusive of the provisions of section $35(2)(c)$. The reference to the provision that "regard shall be had" resurfaced and subtly, but effectively, confirmed the fact that the parental exception to transracial placement in section 35(2)(c) was more apparent than real in its supposed objective from a humanitarian perspective. Defenders of the Government at the time could rely on the pretext that natural parents formed an exception to the rule where their race classification differed from that of their child. However, in practice, this translated differently. Although the terminology used by the Act was vague and ambiguous when stating that "regard" need be had to the racial bar when considering the rights of natural parents, in practice, those persons involved in the placement of children were fully aware of the machinery of the whole Act which, when read holistically, rendered the exception to the racial bar meaningless. Adoption and placement of children in effect continued along the lines that the racial bar was mandatory and not discretionary. In 1964, the courts were called upon to pronounce on the meaning of the provision that "regard shall be had".

\section{Ex Parte Kommissaris van Kindersorg, Boksburg: In Re $N L$}

In 1979, the Supreme Court (as it was then), as upper guardian to all minors, was called upon to determine the validity of an adoption order in Ex Parte Kommissaris van Kindersorg, Boksburg: In Re NL. ${ }^{145}$ The reason was that the commissioner in the adoption application was concerned that he had not paid sufficient attention to the provision of section 35(2)(a). The adoptive parent was classified as belonging to a different race to that of the adoptive child. Under consideration was the question whether sections 35(2)(c) and 71(1)(b), read together, provided a mandatory bar to any placement of a child where the adoptive parents were not the biological parents of such child and were classified as belonging to a different race.

The facts of this case were that an illegitimate child was born of an intimate relationship between the mother of the child, and a coloured man. The mother consented to the adoption of the infant by a black adoptive mother who had been married legally to her coloured husband. The prospective adoptive mother had been re-designated as a "coloured". Before the finalization of the adoption, the prospective adoptive father passed away.

\footnotetext{
144 S16.

1451979 (2) SA 432(T).
} 
Although her husband was deceased, the adoptive mother of the infant resided in a coloured area and was fully accepted within the coloured community. She had been re-designated as "coloured" in terms of the Group Areas Act, ${ }^{146}$ but following the death of her husband and before the adoption was finalized, she reverted to her African status as the Group Areas Act only made provision for re-designation where the marriage of the party subsisted. This marriage was terminated by the death of the husband and before the finalization of the adoption process. The child had been placed in the care of the couple on 14 September 1977. Although the social worker involved supported the proposed adoption and the commissioner signed the consent form, the commissioner was concerned that the adoption was in fact illegal as it was prohibited in terms of section $35(2)(c)$ of the Act. The matter was set down for review by the Supreme Court.

Pending the decision of the court, the child was found to be "in need of care" in terms of section 1(1) of the Children's Act and was placed in the care of the adoptive mother awaiting the decision on review. The court under Esselen $\mathrm{J}$, referred to the decisions of the court in Illingworth $v$ Walmsey ${ }^{147}$ and Joffin $v$ Commissioner of Child Welfare, Springs ${ }^{148}$ with respect to the interpretation of the meaning of "had regard to" in section 35(2). In both instances, the court held that the commissioner retained discretion in reaching a final decision where the race of prospective adoptive parent/s and the infant child differed and that the provision of section 35(2) was not mandatory in nature. The welfare of the child was to be considered in all instances and the court held that it could find no reason to interfere with the decision of the commissioner to allow the adoption of the infant child by the parents. The adoption order was confirmed by the court.

This judgment did not open the door to the judicial approach of transracial adoption and the pattern of placement policies remained the same. Rather, it emphasized the placement of "like-with-like". Esselen J made it clear that he had based his judgment partly on the fact that the adoptive mother had totally integrated into the coloured community - so much so that she was deemed to be coloured in all respects bar her classification in the population register. Furthermore, he was adamant that section 35(2)(c) set a complete bar on transracial fostering or long-term custody placements other than adoption. The decision of the court served as precedent that, other than adoption, such transracial placements were unlawful. Only where the prospective adoptive parent had committed what was referred to as "cultural suicide" and as a result effectively belonged to the same population group as the child's classification, would such transracial adoption be allowed. ${ }^{149}$ Reclassification was not easily achieved and often resulted in other problems, such as the termination of the adult's residential right in the neighbourhood and difficulties with admission to schools. Race-matching in adoption applications remained the norm in South Africa throughout the 1980s.

\footnotetext{
$146 \mathrm{~S} 12(1)(\mathrm{c})(\mathrm{ii})$

147 Supra.

148 Supra.

149 Zaal 1995 SAJHR 376-377.
} 
The Children's Act of 1960, and all its amendments, were replaced by the Child Care Act 74 of $1983 .{ }^{150}$

\section{Child Care Act 74 of 1983}

\section{(i) Introduction}

The Child Care Act was assented to on 15 June 1983 and came into operation on 1 February $1987 .{ }^{151}$ The aim of the Act was to provide inter alia for adoptions and Chapter 4 set out the framework for adoption. ${ }^{152}$ The Act included new developments and mechanisms to change the existing practice of adoption and expanded the possibilities for adoption in South Africa. The status quo regarding private or underhand adoptions was retained and an attempt to secure an adoption in this manner resulted in it being of no force and effect.

\section{(ii) Factors to consider in adoption}

The Act retained the provision that the Children's Court in the district in which a child resided had the jurisdiction to effect an adoption order of the child and all requirements in terms of the Act had to be complied with before an adoption order was granted. Only when a child has been declared as a child in need of care may he or she be made available for adoption. Parents must be "fit and proper" to be entrusted with the custody of a child. Section 17 of the Act stipulates who may adopt such child:

(a) Spouses jointly;

(b) a widower or widow, or an unmarried or divorced person;

(c) a person who is married to the child's parent; or

(d) the natural father of a child born out of wedlock.

The Act provided that the Children's Court "shall have regard" to factors set out in the Act. The single most important requirement when considering adoption was that the proposed adoption should serve the interests of the child and be conducive to the welfare of the child. Davel states that this consideration was ultimately the deciding factor and is to be measured by all factors that will affect the future of the child and is not restricted only to financial and physical comforts. The Constitution provides that the best interests of the child are paramount in all matters concerning the child. The following requirements must also be met:

(a) The court must have regard to the religious and cultural background of the child and his parents, as against that of the prospective parents.

(b) The court must consider the prescribed report from a social worker.

15074 of 1983.

151 The English text was signed by the State President.

152 Ss 17-27. 
(c) The court must be satisfied that the applicant is or both the applicants are qualified to adopt the child; that they have adequate means to maintain and educate the child; that they are of good repute and fit and proper to be entrusted with the custody of the child; and that they qualify for South African citizenship.

(d) The court must be satisfied that the necessary consent for the adoption has been obtained or that it has been dispensed with.

(e) The court must be satisfied that, if relevant, the child has consented to the adoption.

(f) The court must be satisfied that, where required, the child's foster parent has furnished a statement confirming that he or she does not wish to adopt the child.

Of special relevance to this research is the fact that regard need be had to the religious and cultural background of the parties involved in the adoption. Davel suggested that this did not mean that an exact correlation was required in all instances:

\begin{abstract}
"Differences in religious or cultural background would therefore not exclude the possibility of adoption but will be factors taken into consideration when recommending a proposed adoption. Such differences will presumably be more significant where the child to be adopted is older and more likely to have identified with a particular religion or culture and less important where a very young or 'hard to place' child is adopted".
\end{abstract}

Racial classification in the population register dictated that a child could not be placed in the custody of a person where the racial classification of the child and person differed, unless that person was the parent or guardian of the child (section 35(2)(c)).

The effect the adoption is that an adopted child is deemed to be the legitimate child of the adoptive parents for all intents and purposes. After adoption, the adopted child is for all intents and purposes deemed to be the legitimate child of the adopting parent, as if he or she were born of the parent during the existence of a lawful marriage.

Section 28 did not permit adoptions by persons who are married only in terms of religious laws or persons in a polygamous marriage. A further limitation is found where applicants are in a gay or lesbian relationship - only one person can apply to be a legal parent.

This Act retained the status quo in regard to transracial adoption. Provision was made that "regard shall be had" to factors set out in the Act. ${ }^{153}$ These factors included:

(a) The religious and cultural background of the child and his or her parents compared to that of the proposed adoptive parent/s; and,

(b) the racial classification of the child and his or her prospective adoptive parent/s respectively.

153 S 40 
With respect to the religious and cultural background of the parties concerned, every application for adoption had to be considered ad hoc. Boberg ${ }^{154}$ opines that ex hypothesi the cultural and religious background of the parties concerned would carry less weight where the infant was of tender age, and therefore the "matching" of the parties concerned with regard to cultural and religious factors dwindled with the age of the child concerned. ${ }^{155}$ A difference in the official race classification between the child to be adopted and the prospective adoptive parent created an absolute bar to the potential adoption, except where the adopting person/s were the parent/s or guardian/s of the child concerned. The Act provided that a child "shall not be" given in adoption where the race classification of the child and the prospective adoptive parent/s differed.

The Act further provided that certain matters had to be "to the satisfaction" ${ }^{157}$ of the Children's Court before an adoption order was made. The matters concerned were as follows:

(a) The qualification and financial position of the prospective adoptive parent $/ \mathrm{s} ;{ }^{158}$

(b) whether the prospective adoptive parents were "fit" and "of good repute"; ${ }^{159}$

(c) whether the proposed adoption was conducive to the interests and welfare of the child ${ }^{16}$

(d) whether the required consent of the various parties was obtained; and, ${ }^{161}$

(e) South African citizenship as a requirement. ${ }^{162}$

Section 18(4)(c) set the "best interests" of the child as the standard for all adoptions. With respect to the consideration of interests and welfare of the child, the court considered whether the proposed adoption was generally beneficial to the child concerned. All factors were taken into consideration and the circumstances of the child vis-à-vis the proposed adoptive parent/s were considered. In the decision of the court in $R e J$, it was held that the welfare of the child (an infant) was a substantive matter and was not solely determined by money or physical comforts.

Where a child was born of a South African citizen and the prospective adoptive parent was not married to the natural parent of the child, the applicant or one of the applicants concerned had to be a South African citizen resident in the country. Alternatively, the applicant/s needed the

\footnotetext{
Spiro Law of Parent and Child 4ed (1991) 64

The Law of Persons and the Family 359.

156 Ss $18(3)$ and $40(b)$.

157 The difference in the language used by the legislature indicates what is deemed as "overriding" versus "subsidiary" considerations.

$158 \mathrm{~S} 18(4)(\mathrm{a})$

$159 \mathrm{~S} 18(4)(\mathrm{b})$.

$160 \mathrm{~S} 18(4)(\mathrm{c})$.

161 Ss $18(4)(\mathrm{d}), 18(4)(\mathrm{e})$ and $18(4)(\mathrm{g})$.

$162 \mathrm{~S} 18(4)(f)$.
} 
necessary residential qualifications as determined in the African Citizenship $\mathrm{Act}^{163}$ to qualify for the grant of a certificate of naturalization.

The adoption order had the legal effect that all rights and obligations existing between the child and its natural parent/s (and their relatives) were terminated, and the adopted child was deemed legally and for all intents and purposes to be the legitimate child of the adoptive parent/s. ${ }^{164}$ Racial classification in the population register dictated that a child could not be placed in the custody of a person where the racial classification of the child and person differed, unless that person was the parent or guardian of the child (section 35(2)(c)). The question as to whether or not to adopt or promote transracial adoptions led to much debate.

The question as to whether or not to adopt or promote transracial adoptions led to much debate. Mosikatsana made his point clear when he stated as follows:

"(T)ransracial adoptions do not conduce to the welfare of the child, for a child whom is transracially adopted may suffer racial prejudice from the adoptive parents or the community in which the adoptive parents live, which may damage the child's self-concept. Transracial adoptees may also suffer identity crises resulting from the loss of racial or cultural identity, which is fairly important in South Africa, because it is a race-conscious society."

The effect the adoption is that an adopted child is deemed to be the legitimate child of the adoptive parents for all intents and purposes. After adoption, the adopted child is for all intents and purposes deemed to be the legitimate child of the adopting parent, as if he or she were born of the parent during the existence of a lawful marriage.

Section 28 does not permit adoptions by persons who are married only in terms of religious laws or persons in a polygamous marriage. A further limitation is found where applicants are in a gay or lesbian relationship - only one person can apply to be a legal parent. With respect to intercountry adoption, the approach of the legislature was clear. Intercountry adoption was prohibited. The Act was amended by the Child Care Amendment Act 96 of 1996 and section 1 of the Welfare Laws Amendment Act 106 of 1997, the Adoption Matters Amendment Act 56 of 1998 and the Child Care Amendment Act 13 of 1999 .

\section{The Constitutional era}

(i)

\section{Introduction}

It must be noted that intra-country and intercountry adoption differs significantly. Intra-country adoption is a private affair with the involvement of public authorities limited to the role of the commissioner of child welfare

\footnotetext{
Act 44 of 1949.

164 S 20; see Board of Executors v Vitt 1989 (4) SA 480 (C).

165 Mosikatsana "Transracial Adoptions: Are We Learning the Right Lessons from the Americans and Canadians? - A Reply to Professors Joubert and Zaal" 1995112 SALJ 606 611.
} 
concerned and the respective registrar of adoptions. In contrast, intercountry adoptions involve a foreign central authority and foreign accredited adoption service provider, a local central authority and local service provider, and a locally accredited intercountry adoption service provider.

Furthermore, the emphasis in modern law is to seek a permanent placement for a child in need of care in a family environment and to provide the same rights to the child concerned as any other child experiences with his or her natural parents. This is in stark contrast to the focus when arranging the fostering of a child. Fostering of a child is an alternative means of care where a child is orphaned, or his or her parents are unable to take care of the child concerned. When a child is fostered, such child is legally placed in the care of a foster parent. In most instances the care provided is temporary in nature.

“There can be no keener revelation of a society's soul than the way in which it treats its children." This statement by former President Nelson Mandela provides the background against which we must ensure and protect the rights of the children of South Africa.

\section{The Constitution of the Republic of South Africa Act 200} of 1993 (the interim Constitution)

A fundamental change in the legal sphere of South Africa was made with the dawning of the constitutional era in 1994. During the transition to democracy, an interim constitution came into force on 1 April 1994 and remained operative during the drafting of the final Constitution.

This Act established the Constitutional Court as a court of final instance over all matters that related to the interpretation, protection and enforcement of the provisions of the Act. The jurisdiction of the Constitutional Court was not exhaustively defined in the Act. The Act makes provision for the securing and protecting of basic human rights and freedoms, not least of all, within the private context of "family".

(iii) The Constitution of the Republic of South Africa, 1996 (the final Constitution)

The final constitution (the Constitution) was adopted by the Constitutional Assembly in 1996 and became operative on 4 February 1997. The Constitution embraced the principles of democracy. Equality before the law was guaranteed to all. Parliamentary sovereignty was abolished and in terms of the new legal order, the courts were given a testing right with the provisions of the Constitution reigning supreme. The Bill of Rights is of utmost importance and in Daniels v Campbell NO, Ngcobo stated that the Constitution contemplates that there would be a coherent system of law founded on the fundamental principles of human rights and dignity in the Bill of Rights. In terms of the Bill of Rights, a court must apply, or develop, the

166 The Constitution of the Republic of South Africa, 1996 (hereinafter "the Constitution"). 
common law to the extent that our legislation does not give effect to the aims of the Bill.

With the acceptance of the Constitution, a new legal culture was inaugurated with "the objective value order" of the Constitution forming the foundation of legal reasoning. Chaskalson CJ (as he then was) pointed out as follows:

"There is only one system of law. It is shaped by the Constitution which is the supreme law, and all law derives its force from the Constitution and is subject to constitutional control."

The Constitution gives recognition to most sources of South African law, and authorizes the use of both public international law as well as foreign law.

The Constitution provides that every child has the right to family care or parental care or to appropriate alternative care. The legislature had in the explanatory memorandum constitutionalized the right to adoptive care. This provision is in line with article 20 of the Convention on the Rights of the Child (CRC), article 20 of which provides that a child in need of care shall be entitled to special protection from the State and such protection shall include foster placement and adoption.

\section{(iv) The Child Care Amendment Act 96 of 1996}

Certain provisions of the Child Care Act of 1983 were amended by the Child Care Amendment Act in 1996. Joubert provided a summary of the law at that time in South Africa as follows:

(a) Adoption is an institution in the interests of the child.

(b) It must be conducive to the welfare of the child and advance the interests of the child.

(c) The adoptive parents must be found to be "fit and proper".

(d) There was no express prohibition against interracial adoption.

(e) Interracial adoption was therefore legally possible.

\section{The Children's Act 38 of 2005}

With the dawn of the constitutional era, it soon became apparent that the Child Care Act fell short of constitutional provisions, among other shortcomings, and this Act was therefore superseded by the provisions of the Children's Act 38 of 2005 . The Children's Act is constitutionally compliant and is in harmony with international law and international conventions on the rights of children that have been ratified by South Africa. This Act spans a much broader area than its predecessors in its application to children's rights and it provided the much-needed and long-overdue overhaul to adoption 
law. ${ }^{167}$ Previously, child-care legislation was limited to matters concerning adoption matters and children in need of care.

The Act was assented to on 8 June 2005. Certain provisions of the Act came into operation on 1 July 2007, but the remaining provisions became operative in April 2010. Amongst the latter, were Chapter 15 (26 sections, dealing with matters relating to adoption) and Chapter 16 (20 sections on inter-country adoption). Although the legal effect of an adoption order is the same as it was in the 1983 Act, ${ }^{168}$ major changes were effected to the existing legislation regarding the process of adoption. More efficient procedures for the management of adoption were provided, not least of all being the creation of a register for adoptable children and prospective adoptive parents.

The Children's Act provided new developments and mechanisms in order to change adoption practice and expand possibilities for adoption in South Africa. ${ }^{169}$ South Africa is faced with the challenge of an increasing number of orphans and children who are vulnerable and in need of care and placement. Factors such as HIV/AIDS, poverty, illegal immigration and child abandonment all contribute to the current situation in Africa as a whole and South Africa specifically. Both the CRC and the Constitution reinforce the principle that every child has the right to family life or appropriate alternative care. Adoption is clearly a potential solution for these children. South Africa experiences the finalization of adoption for 2500 children nationally per year. In an attempt to increase this number, the Department of Social Development (in partnership with the various relevant stakeholders) was urged to promote adoption services through marketing and public awareness campaigns, both nationally and provincially. It is recognized that there is a need to assess children in foster care to make a determination whether such children could be adopted and a permanent placement could be made.

"Adoption" is defined as the "placement in permanent care of a person in terms of a court order". ${ }^{170}$ Clearly, the rights of a child to protection and care were now constitutionalized. These rights far surpassed the existing alternative form of permanent placement. Security and stability in the life of the child is the primary aim of the former. ${ }^{171}$ The purposes of adoption are listed as being to:

(a) Protect and nurture children by providing a safe, healthy environment with positive support; and,

(b) promote the goals of permanency planning by connecting children to other safe and nurturing family relationships intended to last a lifetime. ${ }^{172}$

The Act provides that any child under the age of 18 years of age, who was not married, was eligible for adoption. The age was set at 18 years in line with the dictates of both the Constitution as well as the CRC (article 1). The

\footnotetext{
167 Adoption is provided for in Chapter 15 of the Act and inter-country adoption is provided for in Chapter 20.

168 Boezaart Child Law in South Africa $133 \mathrm{fn} 3$.

169 Chapter 15.

170 S 228 of the Children's Act 38 of 2005.

171 Discussion Paper 103 on the Review of Child Care Act Project 11025 December 2001.

172 S 229 of the Children's Act 38 of 2005.
} 
Act removed the legal requirements regarding the age of the adoptive parent/s or the age difference between the adoptive parent/s and the child. This was left to the discretion of the adoption agencies and the Children's Court. Through adoption, all parental rights and responsibilities to and for a child, either as parents, step-parents or partners in domestic life partnerships, are terminated. The rights that the child should have experienced while in the care of parents are also terminated by adoption. Hence, on the conclusion of adoption, the adoptive parents become the parents of the adopted child for all intents and purposes.

Opportunities to facilitate adoption are provided for in the Act, one of the most important being that of the Register on Adoptable Children and Prospective Parents (RACAP), whereby an integrated approach to the screening and matching of adoptable children and prospective adoptive parents is created. This register is probably the single most important innovation of the Act. ${ }^{174}$ The aim of the register is to keep a record of all adoptable children and fit and proper adoptive parents. In order to register as an adoptable child, the child must meet the requirements as provided for in section 230 (3) of the Act.

In terms of section 230 :

"(1) any child may be adopted if -

(a) The adoption is in the best interests of the child;

(b) The child is adoptable; and,

(c) The provisions of this Chapter are complied with."

And further:

"(3) A child is adoptable if -

(a) The child is an orphan and has no guardian or care-giver who is willing to adopt the child;

(b) The whereabouts of the child's parents or guardian cannot be established

(c) The child has been abandoned;

(d) the child's parent or guardian has abused or deliberately neglected the child, or has allowed the child to be abused or deliberately neglected; or,

(e) the child is in need of a permanent alternative placement." ${ }^{175}$

The "best interests" of a child is of paramount importance and outweighs any other consideration. "Best interests" includes the child's right to security, need for affection, and continuing and long-term stability. These factors should be the basis for any adoption plan. Section 157(3) provides that adoption should be considered a desirable option. Children who can most benefit are abandoned, neglected, abused and orphaned children.

173 Board of Executors $v$ Vitt 1989 (4) SA 480(C) (A), in which the court held that an adopted child should be included in the term "lawful issue" where this term had been used by the testator who was the adoptive father of the child.

174 Mosikatsana and Loffell Commentary on the Children's Act (2007)15-10; and Boezaart Child Law in South Africa 136.

175 S 230(3). 
Very young children (orphaned or abandoned) should be placed as soon as possible to avoid or limit adjustment problems. The adoption social worker makes an assessment as to whether the child is adoptable or not (section 230(2)), and in certain instances a child may not be deemed adoptable. "'Ad "Adoption social worker" has a limited definition in terms of section 1(1) of the Act.

The Act makes provisions as to who may adopt as follows:

"A child may be adopted -

(a) Jointly by -

(i) A husband and wife;

(ii) Partners in a domestic-life-partnership; or,

(iii) Other persons sharing a common household forming a permanent family unit;

(b) By a widower, widow, divorced or unmarried person;

(c) By a married person whose spouse is the parent of the child or by a person whose permanent domestic life-partner is the parent of the child;

(d) By the biological father of a child born out of wedlock; or,

(e) By the foster parent of the child."177

Prior to the Children's Act, the legislature made citizenship or at least permanent residence a requirement in order for a prospective adoptive person to be registered as a prospective adoptive parent. This requirement led to criticism and South African citizenship is no longer required when adopting a South African child.

The citizenship requirement was held to be unconstitutional in Minister of Welfare and Population Development $v$ Fitzpatrick, ${ }^{178}$ and was subsequently omitted from the Children's Act. ${ }^{179}$ The case involved the possible adoption of a South African child by a British couple who were known to the child as they had fostered the child whilst in South Africa. The High Court reached the decision that section 18(4)(f) of the Child Care Act prohibited such adoptions but that such prohibition was in fact invalid. The finding of the court was suspended for two years to allow the legislature an opportunity to correct the law. The Constitutional Court refused to uphold the suspension of the finding of invalidity and called upon the Ministers to distribute the judgment to the agencies in order to alert them to the possibilities that problems might arise and to advise them as to how such matters might be dealt with in terms of the existing legislation. Following this decision, intercountry adoptions were dealt with in the same manner as intra-country adoptions in terms of Chapter 4 of the Child Care Act. ${ }^{180}$ As a result, a foreigner cannot be registered as an eligible prospective adoptive parent in the register. Davel submits that an explanation for this may lie in the fact that prospective adopters from outside South Africa should be screened by the competent relevant authorities in their country of origin, and not by the South

176 Bosman-Sadie and Corrie (eds) A Practical Approach to the Children's Act (2010).

177 S 231.

178 Supra.

179 Criticized by Davel Child Law in South Africa 136.

180 Louw "Intercountry Adoption in South Africa: Have the Fears become Fact?" 2006 De Jure 504-506. 


\begin{abstract}
African authorities. ${ }^{181}$ This would also be in keeping with the dictates of article 5 of the Hague Convention on Protection of Children and Cooperation in Respect of Intercountry Adoption. ${ }^{182}$ The Children's Act of 2005 expressly permits for another organ of state or an accredited child-protection organization to perform any powers and duties required performing intercountry adoption services. A child-protection organization can be granted accreditation after an application has been made to the Director-General. These accredited organizations play a vital role in providing intercountryadoption services, whilst the Department of Social Development plays an overseeing role in the process. Any fees received by the accredited child protection service are subject to annual auditing and these statements are referred to the relevant Central Authority. This process is done to ensure that no unlawful payments are made in respect of the intercountry adoptions and strict monitoring hereof takes place.
\end{abstract}

$$
\text { Intercountry adoption }
$$

Intercountry adoption first appeared after World War II when many children were orphaned and thus in need of care. Intercountry adoptions were as yet unregulated in South African law, and South Africa had not yet ratified the Hague Convention on the Protection of Children and Co-operation in Respect of Intercountry Adoption. Intercountry adoptions first came under consideration in the South African judicial sphere in Minister of Welfare and Population Development v Fitzpatrick.

The decision of the Constitutional Court in the case confirmed that section $18(4)(f)$ of the Child Care Act was unconstitutional as it prohibited the adoption of South African children by foreigners. The reasoning of the Constitutional Court was that an absolute bar to adoptions by foreigners was contrary to the consideration of the best interests of a child because it had the effect of inflexibility when assessing what was in fact in the best interests of the child. Following the decision of the court in Fitzpatrick, intercountry adoptions are considered legal in South Africa. Although intercountry adoption remains a novelty in South Africa, the practice worldwide of intercountry adoptions has increased over the past six decades as a consequence of various factors, including the globalization of the world and improved world-wide communication. On the African continent it is apparent that a number of children are adopted by Western countries, which are then deemed to be "receiving" countries with Africa being the "sending" country. As such, the African countries act more as suppliers of children to be adopted whilst the Western countries act more as recipients of the children in need of adoption. Increasingly, South Africa can be typified as a sending country given the growing number of abandoned and neglected children as a result, inter alia, of poverty, family breakdown and the rampant spread of HIV/AIDS. Furthermore, it is true to say that the majority of these children are black. We see also instances where the child concerned cannot be taken care of by his or her natural parents or where such children have been

181 Davel and De Kock "In die Kind se Beste Belang” 2001 De Jure 272.

1821993. 
abandoned are absorbed into the extended family system or cared for informally. But where intercountry adoptions are considered, it is essential that the relevant mechanisms are in place to allow for co-operation and collaboration between the relevant authorities - namely, social and medical workers, as well as the legal experts.

\section{CONCLUSION}

The focus of this article has been on the historical development of adoption as a legal institution from the very early practice of adoption, to its inception, distinction and evolution of the principle in Roman law and the reception and development of the concept of adoption in South Africa to date. An historical perspective of adoption serves an important role in an understanding of the fostering of arguments before the courts concerned and provides an explanation of the reasoning behind the decisions reached in specific cases. The history and evolution of adoption is closely linked to the civilizations it emanated from, and it is from an understanding thereof, that a consideration of new factors and developments within the present context of the South African legal system in general, and the international climate in a wider context, can be faced. The understanding of the roots of the concept together with the reasoning and factors behind the evolution of the institution of adoption, gives us a clearer perspective in considering the approaches adopted when facing challenges in this field. 